\title{
The Effect of Knowledge Integration, Knowledge Innovation on New Product Performance: An Empirical Study in Saudi Arabia Firms
}

\author{
Abdullah M. Aldakhil ${ }^{1}$ \\ ${ }^{1}$ Management Department, College of Business Administration, King Saud University, Riyadh, Saudi Arabia \\ Correspondence: Abdullah M. Aldakhil, Management Department, College of Business Administration, King \\ Saud University, Riyadh, Saudi Arabia. E-mail: aaldakhil@hotmail.com
}

Received: August 26, 2015

Accepted: October 16, 2015 Online Published: October 28, 2015

doi:10.5539/ijbm.v10n11p177

URL: http://dx.doi.org/10.5539/ijbm.v10n11p177

\begin{abstract}
The objective of this study is to investigate the effect of knowledge integration, knowledge innovation on new product performance in Saudi Aria firms. In this study, two hypotheses are developed: the relationship between knowledge integration and knowledge innovation; and the relationship between knowledge innovation and new product performance. Federation of the Gulf Cooperation Council (GCC) directory handbook was used as sampling frame for sample selection. A total of 500 firms from food and beverage, chemical and pharmaceutical, automotive, and electronic and telecommunication industry were chosen randomly. The questionnaires were posted along with a cover letter explaining the purpose of study and stressing the confidentiality of responses; a smaller envelop for reply purpose also attached. The majority of manufacturing companies are located in Riyadh, Dammam, and Jeddah as major industrial regions in Saudi Arabia. The results of this study suggest that the knowledge integration indicators have significant contributed in developing knowledge innovation. In fact, utilizing knowledge innovation, firms introduced new ideas, apply knowledge innovation in order achieve competitive advantage have significant effect in increasing the new product performance. In this context, firms should pay attention on those significant indicators in order to achieve competitive advantage in the global market.
\end{abstract}

Keywords: knowledge integration, knowledge innovation, new product performance, Saudi Arabia, firms

\section{Introduction}

Knowledge integration research study is growing substantively. It has become as key source of competitive advantage (Dutta, 1997) and successful business (Alavi \& Leidner, 2001). For example, (Yang, 2005) explains that knowledge integration significantly impact new product performance. For this reason, in increasing new product performance, knowledge integration be influenced by on how participants integrate their individually believed knowledge. Also, knowledge integration is important practice by which firms increase the benefit of knowledge and create competitive advantage. In fact, effective product and process development depends on the integration of a diversity of specific capabilities, robust well-designed groups with interdisciplinary players and various advanced forces (Hung, Kao, \& Chu, 2008; Nellore \& Balachandra, 2001).

Moreover, the phenomenon of knowledge integration is unwell understood both in the literatures and in practices, especially because empirical evidence is missing about how firms can enhance incorporate knowledge in order to make the greatest decisions and solve problems more effectively and efficiently (Fang, Lee, \& Yang, 2015; Hansen, Nohria, \& Tierney, 1999; Liu, Chen, \& Tsai, 2005). This lack of knowledge has direct consequences on the organization's capability to respond to customer requests and improve the operational performance accordingly. Therefore increasing the understanding of knowledge integration is a main purpose of this research. This research also provides a guide for how firms can better manage and integrate their knowledge resources and sustain their competitive advantage in the local and global market.

\section{Literature Review}

\subsection{Knowledge Integration}

Knowledge integration has many definitions. For example, (Hung et al., 2008) define the concept integration as inter-organizational and cross-functional processes using (Kahn, 1996) definition which concentration on interaction and collaboration. Interaction stresses the practice and exchange of communication between 
functional units, and collaboration focuses on the collective work across department (Grant, 1996; Hung et al., 2008; Kahn, 1996). (Alavi \& Tiwana, 2002) define knowledge integration as the combination of individuals' focused on knowledge into situation-specific systemic of knowledge. (Revilla \& Villena, 2012) define knowledge integration as an important capability that allows both buyer and supplier to access, share and exploit knowledge as well as create new knowledge. In this definition, buyers and suppliers share knowledge mostly correlated to existing products and inter-firm processes (e.g., demand development).

In addition, (Yang, 2005) explain knowledge integration within the organization is defined as creating, transferring, sharing and maintaining information and knowledge by understanding of the business context. This definition is in line with resource-based view definition, knowledge represents one of the key elements for obtaining, transforming and integrating other resources (Basaglia, Caporarello, Magni, \& Pennarola, 2010). In fact, (Inkpen \& Dinur, 1998) reveal that knowledge integration could be understood as knowledge development that is designed through formal or informal relationship between individuals and organizations. These internal relationships enable the sharing and communication of new knowledge, and develop a groundwork on which individual knowledge is transmitted into organizational knowledge. In this definition, the knowledge integration model assimilates heterogeneous knowledge inside and outside the firm, arising from vibrant deviations to vertical and horizontal corporate boundaries (Kodama, 2009). Although knowledge integration is important for any organization, they need to possess organizational capabilities to apply some knowledge in organizing resources (Kotabe, Jiang, \& Murray, 2011). In fact, the building blocks of organizational competences or capabilities are individual skills, and both of them are referring to ability to apply some knowledge (Becker \& Zirpoli, 2003). Conversely, (Grant, 1996) argue that an organization's competitiveness derived from knowledge integration and categorized by three factors: efficiency, scope and flexibility of integration. In addition, knowledge integration should be concerned with the practice of proper instruments for handling knowledge complementarities efficiency (Enberg, Lindkvist, \& Tell, 2010; Grant, 1996; Schmickl \& Kieser, 2008). For this reason, (Alavi \& Tiwana, 2002) suggest that knowledge integration will provide a faster and relatively low-cost mechanism because it contains synergistic combination of contrasting specified knowledge without widespread communication or transfer of that knowledge. As a result, knowledge integration can decrease coordination costs, achieve quality improvements, improve production blocks and increase their capabilities to achieve better performance (Revilla \& Villena, 2012).

\subsection{Knowledge Innovation}

Innovation is defined as a new knowledge, the generation of new idea and its implementation in a new product, service or process (Urabe, Child, \& Kagono, 1988). Innovation is considered as an individual and collective learning process that goal to discover new methods of solving problems (Alegre \& Chiva, 2008). In addition, (Chiva, Ghauri, \& Alegre, 2014) describe innovation into four definitions: product, process, marketing, and organizational innovation. These four categories of innovation might have different points of novelty, and therefore might be incremental or radical, that is, based on exploitative or explorative learning (Jansen, Van Den Bosch, \& Volberda, 2006). The difference between incremental and radical innovation is signified by the dissimilarity in novelty amongst the innovation and the existing product or process that it improves (Henderson \& Clark, 1990). It may be the different views that organizations have with respect to innovation (Liu et al., 2005; Veryzer, 1998), and it depends on the overall of experience people in the organization have with the innovation they are developing (Roberts \& Berry, 1984).

For this reason, (Quintane, Casselman, Reiche, \& Nylund, 2011) propose a definition of innovation as an outcome from a knowledge-based viewpoint, and this definition allow for more accuracy in term of assessing the innovativeness of an organization. As a result, innovation appears to depend on the company's competency to study, through which new knowledge are developed, circulated and used (Alegre \& Chiva, 2008). In fact, knowledge help organizations achieve these objectives due to asymmetries information in knowledge across organizations (Lerro, 2012). In this sense, most of scholars are consider new knowledge as the basis for innovation, therefore, an organization's capability to constantly generate innovations is considered as a key important factor in order to achieve competitive advantage in the global market. In addition, the organization innovative capability depends on the intellectual assets and knowledge that it possesses and its ability to organize them (Martín-de Castro et al., 2011).

\subsection{New Product Performance}

New product performance is a multidimensional construct that can be defined and measured at the firm, program, and project levels (Griffin \& Page, 1993). For example, (Cankurtaran, Langerak, \& Griffin, 2013) highlight two dimensions to define new product performance: operational and external outcomes. Operational outcomes based 
on development costs; market entry timing; technical product quality; and product competitive advantage. External outcomes refer to customer-based outcomes and financial outcomes. (Song \& Parry, 1997) identify overall profit, new product sales compared with competitors, profit rate for new product compared with competitors, and new product profit compared with the expected profit as indicator to measure new product performance. (Liu et al., 2005) define new product performance based on life cycle of new product, sales amount and profit for new product, and time to market for new product.

In addition, (Troy, Hirunyawipada, \& Paswan, 2008) suggest that new product performance can be measured as either an objective assessment or a subjective assessment. Objective assessment is documented return on investment, sales, market share, and profits. Subjective assessment is managers' perceptions of how well the new product performed relative to expectations. (Barczak, Sultan, \& Hultink, 2007) define new product performance refer to speed to market and market performance. Speed to market refers to the time engaged to deliver a product from idea formation to market launch. The shorter this cycle time, the faster the product is brought to market. Market performance refers to the point to which the new product achieve the expected sales, market share, profitability, market performance, and customer satisfaction.

For this reason, (Handfield, Ragatz, Peterson, \& Monczka, 1999) suggest that there are two important factors that the organizations have to consider in deciding to integrate product development process: the rate of technology change and the level of supplier expertise in providing the technology services. In this definition, new product performance not only emphasize on the quality of development process leading up to the introduction of a new product, but also the quality of the new product itself (Coenen \& Kok, 2014).

\section{Hypotheses Development}

\subsection{Knowledge Integration, Knowledge Innovation and New Product Performance}

Previous studies have provided some empirical support and theories the relationship between knowledge integration, knowledge innovation and new product performance across industries. For example, (Yang, 2005) found that knowledge integration and knowledge innovation are significant and both of these dimensions have significant effects on new product performance. (Xin, Yeung, \& Cheng, 2010) suggest that a better organization position to develop technological innovative product will increase a better organization performance. High innovative products will provide firms in order to achieve competitive advantage in the global market and generate sales (Calantone, Harmancioglu, \& Droge, 2010; Chiva et al., 2014; Liu et al., 2005; Wang \& Wang, 2012). As a result, highly technology innovative products have a tendency to face low competition at the point of its introduction and subsequently generate a relatively high profit to the introducing firm (Roberts, 1999; Xin et al., 2010). In this context, new product innovation can be seen as a unique capability in term of creating superior and novel products in order to inspire firms to be market oriented (Calantone et al., 2010). Consequently, (Narver \& Slater, 1990) suggest that market-oriented firms most effectively and efficiently in generating superior value for customers and achieve competitive advantage; thus, the firm's strategic orientation for both customer and competitor will play significant role in the new product development process (Calantone et al., 2010; Fidel, Schlesinger, \& Cervera, 2015; Narver, Slater, \& MacLachlan, 2004).

In addition, (Yang, 2005) suggest that employees skilled and experienced have significant contribution in improving new product performance and profitability. Other scholars also highlight the importance of human resource practices such as talent development and requisite skills (Amin, Ismail, Rasid, \& Selemani, 2014; O'Connor, 2008), and workplace flexibility to improve new product performance (Coenen \& Kok, 2014). When an firm obtains knowledge through training, the learned knowledge will be spread and accumulated to become a valued asset through a knowledge integration process including human, organizational and procedural interaction, then firm performance will be increased accordingly (Zhao, Qi, \& De Pablos, 2014). Consequently, a firm's ability to transform knowledge might determine its level of innovation, such as new problem-solving approaches and new product development strategies (Liu et al., 2005; Zhao et al., 2014). Thus, the following hypotheses are:

H1: There is a significant relationship between knowledge integration and knowledge innovation.

H2: There is a significant relationship between knowledge innovation and new product performance

\section{Methodology}

\subsection{Measurement Scale and Data Collection Process}

In this study, three items to measure knowledge integration were adopted from (Yang, 2005) and (Huang \& Newell, 2003), and then adapted to Saudi Arabia industry context. Knowledge innovation scales were adapted from (Yang, 2005), while new product performance was adapted from (Yang, 2005) and (Liu et al., 2005). A five point Likert-scale were employed from 1 - strongly disagree to 5 - strongly agree. 
Federation of the Gulf Cooperation Council (GCC) directory handbook was used as sampling frame for sample selection. A total of 500 firms from food and beverage, chemical and pharmaceutical, automotive, and electronic and telecommunication industry were chosen randomly. Firms involved in this study have annual sales between SAR10 million to more than SAR500 million, and between 50 to more than 500 full time employees. A total of 500 firms were successfully approached by mail and follow up by phone requesting them to contribute in this study from December 2014 to February 2015, yielding a response rate of 24\% (121 firms). The questionnaires were posted along with a cover letter explaining the purpose of study and stressing the confidentiality of responses; a smaller envelop for reply purpose also attached. The majority of manufacturing companies are located in Riyadh, Dammam, and Jeddah as major industrial regions in Saudi Arabia.

\section{Data Analysis and Results}

\subsection{Industries Characteristic}

Table 1 shows the industries demographic characteristic. The result of this study consisted of food and beverages $(19.8 \%)$, chemical and pharmaceutical $(26.4 \%)$, automotive $(6.4 \%)$, and electronic and telecommunication industry (47.1\%).

Table 1. Industry characteristics

\begin{tabular}{llll}
\hline Characteristics & Group & Number of respondents & Percentage of respondents \\
\hline Industry & Food \& Beverage & 24 & 19.8 \\
& Chemical \& Pharmaceutical & 32 & 26.4 \\
& Automotive & 8 & 6.4 \\
Electronic & \& & 47.1 \\
Telecommunication & & \\
No. employees & $1-50$ & 2 & 1.7 \\
& $51-100$ & 11 & 9.1 \\
& $101-500$ & 33 & 27.3 \\
Annual Sales & Above 500 & 75 & 62 \\
& $0-10$ & 7 & 5.8 \\
& $11-50$ & 17 & 14 \\
& $51-99$ & 11 & 9.1 \\
& $100-500$ & 13 & 10.7 \\
& Above 500 & 73 & 60.3 \\
\hline
\end{tabular}

\subsection{Exploratory Factor Analysis}

Table 2 displays the exploratory factor analysis results. The principal component factor analysis with varimax rotation method was employed in this study. The Kaiser-Meyer-Olkin (KMO) value was 0.902 which is above the suggested level, and Bartlett's test of sphericity is significant. The results of principal component factor analysis show that the three factors with eigen values greater than 1 and explaining cumulatively $67 \%$ of the variance. The three factors have loading from 0.743 to 0.900 which is above the recommended level of 0.50 . As each factor loading on each construct was more than 0.50 , the convergent validity for each construct was established, thereby providing indication of construct validity for all the constructs in this study (Anderson \& Gerbing, 1988; Hair, Tatham, Anderson, \& Black, 1998). In addition, AVE (average variance extracted) was calculated for each construct and the AVE ranged from 0.656 to 0.685 .

\subsection{Regression analysis}

Table 3 present the results of regression analysis with statistically significant level at $5 \%$. The results explain that knowledge integration and knowledge innovation have significant relationship on new product performance ( $\mathrm{p}$-value $=0.001, \beta=0.634 ; \mathrm{p}$-value $=0.001, \beta=0.733)$. Thus, $\mathrm{H} 1$ and $\mathrm{H} 2$ were supported. 
Table 2. Exploratory factor analysis

\begin{tabular}{|c|c|c|c|}
\hline \multirow{2}{*}{ Dimension } & & \multicolumn{2}{|l|}{ Factor } \\
\hline & & 1 & 3 \\
\hline \multicolumn{4}{|l|}{ Knowledge Integration(Cronbach Alpha $=0.890 ;$ Average Variance Extracted $=0.679$ ) } \\
\hline Teams have been established strictly for the purpose of knowledge integration & 0.756 & & \\
\hline $\begin{array}{l}\text { Cooperative agreements are in place to facilitate knowledge integration between your organization and your } \\
\text { suppliers }\end{array}$ & 0.900 & & \\
\hline Acquired project-related knowledge has been integrated together for project use & 0.810 & & \\
\hline \multicolumn{4}{|l|}{ Knowledge Innovation (Cronbach Alpha $=0.879 ;$ Average Variance Extracted $=0.656$ ) } \\
\hline Your firm producing knowledge as a product & & 0.834 & \\
\hline Utilize knowledge innovation in order to maintain a competitive advantage in the market & & 0.775 & \\
\hline Your firm introduced new ideas about your process, product, and project & & 0.743 & \\
\hline Apply knowledge innovation to increase causal ambiguity to deter competitors & & 0.881 & \\
\hline \multicolumn{4}{|l|}{ New Product Performance (Cronbach Alpha $=0.922 ;$ Average Variance Extracted $=0.685$ ) } \\
\hline Sales relative to its stated objective & & & 0.835 \\
\hline Profit margin relative to its stated objective & & & 0.796 \\
\hline Return on assets relative to its stated objective & & & 0.812 \\
\hline Return on investment relative to its stated objective & & & 0.867 \\
\hline
\end{tabular}

Table 4. Regression analysis

\begin{tabular}{lllll}
\hline Dependent variables & $\begin{array}{l}\text { Standardized } \\
\text { Coefficients }\end{array}$ & t-value & p-value & Hypothesis \\
\hline Knowledge integration & 0.634 & 5.225 & $0.001^{*}$ & Supported \\
Knowledge innovation & 0.733 & 5.772 & $0.001^{*}$ & Supported \\
\hline
\end{tabular}

\section{Discussion and Managerial Implications}

The objective of this study is to examine the effect of knowledge integration and knowledge innovation on new product performance. The results of this study suggest that the knowledge integration indicators (firms have teams established knowledge integration, cooperative parties mutual agreement between organizations and suppliers, and project-related knowledge integrated) have significant contributed in developing knowledge innovation. In fact, utilizing knowledge innovation, firms introduced new ideas, apply knowledge innovation in order achieve competitive advantage have significant effect in increasing new product performance. In this context, firms should pay attention on those significant indicators in order to achieve competitive advantage in the global market. In addition, the findings of this study are consistent with previous study (Liu et al., 2005; Yang, 2005).

The results clearly indicate that firms are not implement knowledge integration and knowledge innovation has potential lowest new product performance. For example, (Hung et al., 2008) explained that inter-firms collaborative product development and engineering knowledge are an important asset for technology-based industry in enhancing business strategy and product development in the global market. In fact, (Calantone et al., 2010) highlight that new product performance is a direct relationship on innovation and contributes firms in increasing firm performance. Consequently, workplace flexibility is another indicator will effect new product performance through enabling knowledge sharing and inter-organizational involvement (Coenen \& Kok, 2014). Therefore, firm learning, innovation, and enforces their employees to continuous learning and innovating on a new product in order to enhancing firms performance are becoming important aspect. In this context, (Chiva et al., 2014) suggest that firm managers have to understand the holistic organizations structure and characteristics in implementing knowledge integration and knowledge innovation to provide more innovative employees and product developments. In fact, more innovative and differentiate products will provide more value to customers and firms will get more advantage (Sengupta, 1998).

Although, most studies conclude that the importance of innovation to new product performance is universal, however, firm managers have to understand this direction to firm performance improvement. As a result, firms performance outcome become important when firms implementing knowledge integration and innovation (Cohen \& Olsen, 2015). In addition, firm managers should include customer input in managing their overall new product development programs and systematic firm structures to raise innovation (Calantone et al., 2010). For this reason, firm managers should prioritize knowledge integration practices in order to enhance knowledge 
innovation and new product performance outcomes.

Some limitation from this study should be noted. First, sampling frame from three big cities in Saudi Arabia cannot be generalized the results interpretation. Future research should include other potential industrial cities to generate more general results. Second, this study is not control firms size and technology infrastructures, and its significant impact on knowledge integration, knowledge innovation, and new product performance. Future research should include those dimensions.

\section{Acknowledgements}

The researcher would like to thank the Deanship of Scientific Research at King Saud University represented by the Research Center in the College of Business Administration for financially supporting this research.

\section{References}

Alavi, M., \& Leidner, D. E. (2001). Review: Knowledge management and knowledge management systems: Conceptual foundations and research issues. MIS Quarterly, 107-136. http://dx.doi.org/10.2307/3250961

Alavi, M., \& Tiwana, A. (2002). Knowledge integration in virtual teams: The potential role of KMS. Journal of the American Society for Information Science and Technology, 53(12), 1029-1037. http://dx.doi.org/10.1002/asi.10107

Alegre, J., \& Chiva, R. (2008). Assessing the impact of organizational learning capability on product innovation $\begin{array}{llll}\text { performance: An empirical } & \text { test. }\end{array}$ http://dx.doi.org/10.1016/j.technovation.2007.09.003

Amin, M., Ismail, W. K. W., Rasid, S. Z. A., \& Selemani, R. D. A. (2014). The impact of human resource management practices on performance: Evidence from a Public University. The TQM Journal, 26(2), 125-142. http://dx.doi.org/10.1108/TQM-10-2011-0062

Anderson, J. C., \& Gerbing, D. W. (1988). Structural equation modelling in practice: A review and recommended two-step approach. Psychological Bulletin, 103(3), 411-423. http://dx.doi.org/10.1037/0033-2909.103.3.411

Barczak, G., Sultan, F., \& Hultink, E. J. (2007). Determinants of IT Usage and New Product Performance. $\begin{array}{llll}\text { Journal of Product Innovation } & \text { Management, 24(6), }\end{array}$ http://dx.doi.org/10.1111/j.1540-5885.2007.00274.x

Basaglia, S., Caporarello, L., Magni, M., \& Pennarola, F. (2010). IT knowledge integration capability and team performance: The role of team climate. International Journal of Information Management, 30(6), 542-551. http://dx.doi.org/10.1016/j.ijinfomgt.2010.04.003

Becker, M. C., \& Zirpoli, F. (2003). Organizing new product development: Knowledge hollowing-out and knowledge integration-the Fiat Auto case. International Journal of Operations \& Production Management, 23(9), 1033-1061. http://dx.doi.org/10.1108/01443570310491765

Calantone, R. J., Harmancioglu, N., \& Droge, C. (2010). Inconclusive Innovation "Returns": A Meta-Analysis of Research on Innovation in New Product Development. Journal of Product Innovation Management, 27(7), 1065-1081. http://dx.doi.org/10.1111/j.1540-5885.2010.00771.x

Cankurtaran, P., Langerak, F., \& Griffin, A. (2013). Consequences of New Product Development Speed: A Meta-Analysis. Journal of Product Innovation Management, 30(3), 465-486. http://dx.doi.org/10.1111/jpim.12011

Chiva, R., Ghauri, P., \& Alegre, J. (2014). Organizational learning, innovation and internationalization: A complex system model. British Journal of Management, 25(4), 687-705. http://dx.doi.org/10.1111/1467-8551.12026

Coenen, M., \& Kok, R. A. (2014). Workplace flexibility and new product development performance: The role of telework and flexible work schedules. European Management Journal, 32(4), 564-576. http://dx.doi.org/10.1016/j.emj.2013.12.003

Cohen, J. F., \& Olsen, K. (2015). Knowledge management capabilities and firm performance: A test of universalistic, contingency and complementarity perspectives. Expert Systems with Applications, 42(3), 1178-1188. http://dx.doi.org/10.1016/j.eswa.2014.09.002

Dutta, S. (1997). Strategies for implementing knowledge-based systems. Engineering Management, IEEE Transactions on, 44(1), 79-90. http://dx.doi.org/10.1109/17.552810 
Enberg, C., Lindkvist, L., \& Tell, F. (2010). Knowledge integration at the edge of technology: On teamwork and complexity in new turbine development. International Journal of Project Management, 28(8), 756-765. http://dx.doi.org/10.1016/j.ijproman.2010.05.003

Fang, E., Lee, J., \& Yang, Z. (2015). The Timing of Codevelopment Alliances in New Product Development Processes: Returns for Upstream and Downstream Partners. Journal of Marketing, 79(1), 64-82. http://dx.doi.org/10.1509/jm.13.0490

Fidel, P., Schlesinger, W., \& Cervera, A. (2015). Collaborating to innovate: Effects on customer knowledge management and performance. Journal of Business Research, 68(7), 1426-1428. http://dx.doi.org/10.1016/j.jbusres.2015.01.026

Grant, R. M. (1996). Prospering in dynamically-competitive environments: Organizational capability as knowledge integration. Organization Science, 7(4), 375-387. http://dx.doi.org/10.1287/orsc.7.4.375

Griffin, A., \& Page, A. L. (1993). An interim report on measuring product development success and failure. Journal of Product Innovation Management, 10(4), 291-308.

Hair, J., Tatham, R., Anderson, R., \& Black, W. (1998). Multivariate Data Analysis (5th ed.). Prentice Hall.

Handfield, R. B., Ragatz, G. L., Peterson, K., \& Monczka, R. M. (1999). Involving suppliers in new product development? California Management Review, 42, 59-82.

Hansen, M. T., Nohria, N., \& Tierney, T. (1999). What's your strategy for managing knowledge? The Knowledge Management Yearbook 2000-2001.

Henderson, R. M., \& Clark, K. B. (1990). Architectural innovation: The reconfiguration of existing product technologies and the failure of established firms. Administrative Science Quarterly, 9-30. http://dx.doi.org/10.2307/2393549

Huang, J. C., \& Newell, S. (2003). Knowledge integration processes and dynamics within the context of cross-functional projects. International Journal of Project Management, 21(3), 167-176. http://dx.doi.org/10.1016/S0263-7863(02)00091-1

Hung, H. F., Kao, H. P., \& Chu, Y. Y. (2008). An empirical study on knowledge integration, technology innovation and experimental practice. Expert Systems with Applications, 35(1), 177-186. http://dx.doi.org/10.1016/j.eswa.2007.06.017

Inkpen, A. C., \& Dinur, A. (1998). Knowledge management processes and international joint ventures. Organization Science, 9(4), 454-468. http://dx.doi.org/10.1287/orsc.9.4.454

Jansen, J. J., Van Den Bosch, F. A., \& Volberda, H. W. (2006). Exploratory innovation, exploitative innovation, and performance: Effects of organizational antecedents and environmental moderators. Management Science, 52(11), 1661-1674. http://dx.doi.org/10.1287/mnsc.1060.0576

Kahn, K. B. (1996). Interdepartmental integration: A definition with implications for product development performance. Journal of Product Innovation Management, 13(2), 137-151.

Kodama, M. (2009). Boundaries innovation and knowledge integration in the Japanese firm. Long Range Planning, 42(4), 463-494. http://dx.doi.org/10.1016/j.lrp.2009.08.001

Kotabe, M., Jiang, C. X., \& Murray, J. Y. (2011). Managerial ties, knowledge acquisition, realized absorptive capacity and new product market performance of emerging multinational companies: A case of China. Journal of World Business, 46(2), 166-176. http://dx.doi.org/10.1016/j.jwb.2010.05.005

Lerro, A. (2012). Knowledge-based perspectives of innovation and performance improvement in health care. Measuring Business Excellence, 16(4), 3-13. http://dx.doi.org/10.1108/13683041211276401

Liu, P. L., Chen, W. C., \& Tsai, C. H. (2005). An empirical study on the correlation between the knowledge management method and new product development strategy on product performance in Taiwan's industries. Technovation, 25(6), 637-644. http://dx.doi.org/10.1016/j.technovation.2003.11.001

Martín-de Castro, G., López-Sáez, P., Delgado-Verde, M., Martín-de Castro, G., López-Sáez, P., \& Delgado-Verde, M. (2011). Towards a knowledge-based view of firm innovation. Theory and empirical $\begin{array}{llll}\text { research. Journal of Knowledge } & \text { Management, } & \text { 15(6), }\end{array}$ http://dx.doi.org/10.1108/13673271111179253

Narver, J. C., \& Slater, S. F. (1990). The effect of a market orientation on business profitability. Journal of Marketing, 54(4). http://www.jstor.org/stable/1251757 
Narver, J. C., Slater, S. F., \& MacLachlan, D. L. (2004). Responsive and Proactive Market Orientation and New-Product Success. Journal of Product Innovation Management, 21(5), 334-347. http://dx.doi.org/10.1111/j.0737-6782.2004.00086.x

Nellore, R., \& Balachandra, R. (2001). Factors influencing success in integrated product development (IPD) projects. Engineering Management, IEEE Transactions on, 48(2), 164-174. http://dx.doi.org/10.1109/17.922476

O'Connor, G. C. (2008). Major innovation as a dynamic capability: A systems approach. Journal of Product Innovation Management, 25(4), 313-330. http://dx.doi.org/10.1111/j.1540-5885.2008.00304.x

Quintane, E., Casselman, R. M., Reiche, B. S., \& Nylund, P. A. (2011). Innovation as a knowledge-based $\begin{array}{llll}\text { outcome. Journal of Knowledge } & \text { Management, } & \text { 15(6), }\end{array}$ http://dx.doi.org/10.1108/13673271111179299

Revilla, E., \& Villena, V. H. (2012). Knowledge integration taxonomy in buyer-supplier relationships: Trade-offs between efficiency and innovation. International Journal of Production Economics, 140(2), 854-864. http://dx.doi.org/10.1016/j.ijpe.2012.07.002

Roberts, E. B., \& Berry, C. A. (1984). Entering new businesses: Selecting strategies for success.

Roberts, P. W. (1999). Product innovation, product-market competition and persistent profitability in the US pharmaceutical industry. Strategic Management Journal, 20(7), 655-670.

Schmickl, C., \& Kieser, A. (2008). How much do specialists have to learn from each other when they jointly develop radical product innovations? Research Policy, 37(3), 473-491. http://dx.doi.org/10.1016/j.respol.2007.12.001

Sengupta, S. (1998). Some approaches to complementary product strategy. Journal of Product Innovation Management, 15(4), 352-367. http://dx.doi.org/10.1111/1540-5885.1540352

Song, X. M., \& Parry, M. E. (1997). A cross-national comparative study of new product development processes: Japan and the United States. The Journal of Marketing, 1-18. http://dx.doi.org/10.2307/1251827

Troy, L. C., Hirunyawipada, T., \& Paswan, A. K. (2008). Cross-functional integration and new product success: An empirical investigation of the findings. Journal of Marketing, 72(6), 132-146. http://dx.doi.org/10.1509/jmkg.72.6.132

Urabe, K., Child, J., \& Kagono, T. (1988). Innovation and Management: International Comparisons. Walter de Gruyter.

Veryzer, R. W. (1998). Discontinuous innovation and the new product development process. Journal of Product Innovation Management, 15(4), 304-321. http://dx.doi.org/10.1016/j.emj.2013.12.003

Wang, Z., \& Wang, N. (2012). Knowledge sharing, innovation and firm performance. Expert Systems with applications, 39(10), 8899-8908. http://dx.doi.org/10.1016/j.eswa.2012.02.017

Xin, J. Y., Yeung, A. C., \& Cheng, T. (2010). First to market: Is technological innovation in new product development profitable in health care industries? International Journal of Production Economics, 127(1), 129-135. http://dx.doi.org/10.1016/j.jpe.2010.05.004

Yang, J. (2005). Knowledge integration and innovation: Securing new product advantage in high technology industry. The Journal of High Technology Management Research, 16(1), 121-135. http://dx.doi.org/10.1016/j.hitech.2005.06.007

Zhao, J., Qi, Z., \& De Pablos, P. O. (2014). Enhancing enterprise training performance: Perspectives from knowledge transfer and integration. Computers in Human Behavior, 30, 567-573. http://dx.doi.org/10.1016/j.chb.2013.06.041

\section{Copyrights}

Copyright for this article is retained by the author(s), with first publication rights granted to the journal.

This is an open-access article distributed under the terms and conditions of the Creative Commons Attribution license (http://creativecommons.org/licenses/by/3.0/). 